\title{
Virus against Soil Fertilizers?
}

\section{Navarrete JM*, Morales OY and García Batlle M \\ Department of Inorganic and Nuclear Chemistry, National University of Mexico}

Submission: April 08, 2017; Published: June 05, 2017

*Corresponding authors: Navarrete JM, Department of Inorganic and Nuclear Chemistry, National University of Mexico, Mexico,

Tel: (+5255)56225232; E-mail: jmnat33@unam.mx

\begin{abstract}
The fertilizers effect on farming crops seems to be a better adsorption of minerals elements present in soil, which determined a better development on growing crops. This good effect is produced by water taking elements in solution, that is to say ions or electrolytes going up from soil to vegetables tissues. But, what is the effect of soil fertilizers when they are ingested either by animals or human beings? This short communication aims to show some preliminary results obtained when solution of one molecule successfully used as fertilizer has been ingested by laboratory mice and rats in drinking water with some radioactive labeled electrolytes in solution such as ${ }^{45} \mathrm{Ca}^{2+},{ }^{59} \mathrm{Fe}^{3+},{ }^{32} \mathrm{PO}_{4}^{3-}$, ${ }^{131}$ I: Filtration through liver from digestive tract to blood was increased by a factor from 2 to 3 , same that Iodine concentration in thyroid gland; this increment in circulating electrolytes had a second effect: IgG measured by ELISA technique is also increased by a factor from 2 to 3. These results might be considered reliable enough to test these effects on human beings by means of a medical protocol, but even when fulvic acids as the main fertilizers active principle, has been authorized as nourishing complement, medical protocol has not been possible till now.
\end{abstract}

Keywords: Fertilizers; Labelled electrolytes; Immunoglobulins

\section{Introduction}

Besides the good effects cited the only drawback found was one slight deficiency in weight, probably due to some purgative properties of fulvic acids. Table 1 shows preliminary results obtained from one group of 8 mice drinking water with fulvic acid concentration $6.75 \mathrm{mg} / \mathrm{mL}$ during one month including increment in IgGmg/mL and weight loss [1].

Table 1: Concentration of $\lg G$ and total immunoglobulin $(\mathrm{mg} / \mathrm{mL})$.

\begin{tabular}{|c|c|c|c|c|c|c|}
\hline & \multicolumn{3}{|c|}{$\begin{array}{c}\text { Mice Drinking } \\
\text { Fa + labelled Ions }\end{array}$} & \multicolumn{3}{|c|}{ Mice Drinking Just Labelled Ions } \\
\hline & IgG & Total Ig & $\begin{array}{c}\text { Weight } \\
\text { (g) }\end{array}$ & IgG & Total Ig & $\begin{array}{c}\text { Weight } \\
\text { (g) }\end{array}$ \\
\hline 1 & 56.2 & 88 & 30.2 & 18.5 & 72 & 39.8 \\
\hline 2 & 40.2 & 80 & 33.4 & 30.1 & 70 & 40.4 \\
\hline 3 & 71.2 & 78 & 32.6 & 19.8 & 70 & 37.6 \\
\hline 4 & 59.0 & 78 & 35.1 & 12.8 & 66 & 38.8 \\
\hline 5 & 80.1 & 85 & 30.9 & 25.6 & 70 & 39.2 \\
\hline 6 & 53.1 & 84 & 31.5 & 22.7 & 68 & 41.6 \\
\hline 7 & 72.1 & 82 & 33.8 & 31.3 & 68 & 40.2 \\
\hline 8 & 52.8 & 86 & 34.7 & 15.6 & 70 & 39.5 \\
\hline Average & 60.7 & 82.6 & 32.7 & 22.0 & 69.2 & 39.6 \\
\hline Std.Dev. & \pm 12.8 & \pm 3.7 & \pm 1.8 & \pm 6.6 & \pm 1.8 & \pm 1.2 \\
\hline
\end{tabular}




\section{Conclusion}

The obtained results till now are not conclusive in anyway, but they are not negligible. They seem to deserve some more attention in the way to one medical protocol, in view of empirical effects showed by cattle, poultry and pigs such as larger milk production, lower number of miscarriages and of course better resistant to viral infections. It also seems highly probable that if tested in human beings, results might be analogous $[2,3]$.

\section{References}

1. Morales OY (2012) Fulvic acids effects on vertebrate's physiology determined by radioactive tracers. Faculty of Chemistry. National University of Mexico.
2. Morales OY, Navarrete JM, Gracia I, Macías L, Rivera M, et al. (2012) Fulvic acids and viral infections. The Open Conference Proceedings Journal 3: 1-6.

3. Morales OY, Navarrete JM, Gracia I, Macías L, Rivera M, et al. (2011) Effect of fulvic acid on the electrolytes physiology in vertebrates. Nuclear Instruments and Methods in Physics Research A Vol 652: 838840 .

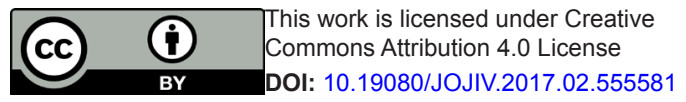

Your next submission with Juniper Publishers will reach you the below assets

- Quality Editorial service

- Swift Peer Review

- Reprints availability

- E-prints Service

- Manuscript Podcast for convenient understanding

- Global attainment for your research

- Manuscript accessibility in different formats ( Pdf, E-pub, Full Text, Audio)

- Unceasing customer service

Track the below URL for one-step submission https://juniperpublishers.com/online-submission.php 